\title{
Chapter 18 \\ The Crisis of Latin American Regionalism and Way Ahead
}

\author{
José Briceño-Ruiz and Andrea Ribeiro Hoffmann
}

\begin{abstract}
This chapter analyses the crisis of Latin America regionalism focusing on the changes and continuities of regional organizations such as UNASUR, Mercosur, ALBA and Pacific Alliance and discusses future scenarios.
\end{abstract}

\section{Introduction}

The main objective of this chapter is to understand how the global crisis that started in 2008 in the USA and national crisis in countries such as Brazil and Venezuela have affected Latin American regionalism. The chapter also explores how Latin American regionalism could be reconfigured under the new conditions. The prevailing narrative about the impact of the crisis in Latin American regionalism is negative given the expected impact of the current trends on asymmetries among and within countries. The previous period of post-liberal and post-hegemonic regionalism, despite its fragilities, was one of diminishing poverty and inequalities, and increasing inclusion and participation of traditionally excluded sectors of the society in the political processes. The current turn to neoliberalism together with rise of democratic instability and extreme-right movements have not only uncovered the fragilities of the achievements of the last decade, but also put into question the strategies pursued by the previous governments, creating a paralysis, a vacuum of forward-looking alternatives.

In this chapter, we firstly assess the development of the Southern Common Market (Mercosur), the Union of South American Nations (UNASUR), The Bolivarian Alternative for the Peoples of the Americas (ALBA) and the Pacific

\footnotetext{
J. Briceño-Ruiz

National Autonomous University of México (UNAM), México City, Mexico

e-mail: bricenoruiz@unam.mx
}

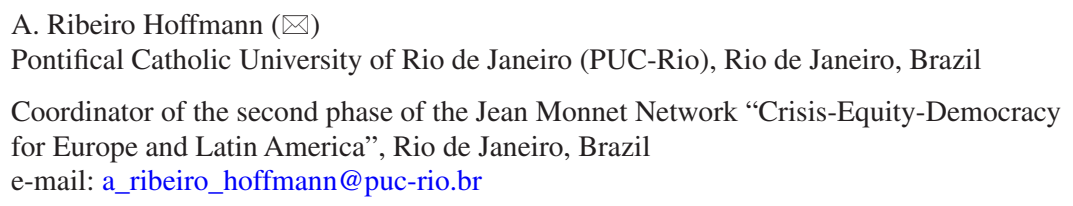


Alliance during the last decade and how they have reacted and adapted differently to global and local level pressures. However, these organizations are also deeply intertwined, as they exist in a complex network of overlapping memberships and mandates, and therefore, we analyse these interconnections and common trends for Latin American regionalism as a whole in the last section of the chapter. We also reflect on the alternative future scenarios.

\section{Mercosur: From Open Regionalism to Post-Liberal Regionalism and Back?}

From the regional organizations analysed in this chapter, Mercosur is the only one that was created in the early 1990s, during the so-called second wave of regionalism. Its main objective, as stated in the constitutive Treaty of Asuncion, was to create a common market in order to accelerate economic development with social justice and achieve a better insertion in the global economy. Mercosur was conceived as part of a strategy of incorporation into the processes of globalization in line with the concept of open regionalism, as an intermediary stage for the expansion of domestic markets and internationalization of local firms, as well as a platform to negotiate the Free Trade Area of the Americas (FTAA) (Bianculli 2016). Other, implicit, objectives were to lock-in democracy and de-securitize relations after the end of the Cold War (Oelsner 2014).

For about a decade, Mercosur was considered successful in fulfilling these aims, until an economic crisis which led to the devaluation of Brazilian currency in 1999, and a generalized crisis in Argentina in 2001. Despite a brief period of 'soul searching' (Bouzas 2002) thereafter, Mercosur's project was renovated; its free-trade-oriented agenda was transformed, and a model of social development was implemented, in line with the centre-left leaning governments at the time. Over almost 30 years of existence, Mercosur promoted norms and regulations in several issue areas, with different record of success in terms of achieving agreements on common positions and implementation. Mercosur was considerably successful in promoting free mobility of goods and persons, health and education regulations, and human rights, for instance, but less successful in promoting the free mobility of services and capital, and the protection of democracy. It has not played an important role in security and defence, but, overall, Mercosur remained until recently a tacit agreement among its member-states governments and societies (Ribeiro Hoffmann 2020).

The declaration from Paulo Guedes, Minister of Economics of President Bolsonaro in Brazil criticizing Mercosur, has raised the suspicion about the fate of this organization. ${ }^{1}$ The leadership, or at least strong support, of Brazil to Mercosur

\footnotetext{
${ }^{1}$ https://g1.globo.com/economia/noticia/2018/10/30/declaracoes-de-paulo-guedes-sobre-mercosul-surpreendem-membros-do-bloco.ghtml; https://g1.globo.com/economia/blog/joao-borges/ post/2018/11/02/paulo-guedes-pretende-fortalecer-politica-de-comercio-exterior.ghtml.
} 
is a key condition for its relevance as a regional organization in Latin America, even if Brazil cannot be defined as a regional hegemon in traditional terms, its size matters (Soares and Hirst 2006; Merke 2015). While other organizations in the region such as UNASUR include 'secondary powers' or 'middle powers' in addition to Argentina, such as Chile, Peru and Colombia (Ruvalcaba et al. 2016) that combined have leadership capacity to advance a common project, this is not the case of Mercosur. One way to analyse the impact of the crisis on Mercosur is, therefore, through the changes in Brazilian interests and foreign policy towards this organization.

Despite the traditional strength of the Brazilian Ministry of Foreign Affairs (Itamaraty), and its historical preference for continuity, Brazilian foreign policy has become more susceptible to changing governments during the last decade, with an increased role of presidents in the agenda setting, a phenomenon referred to as 'presidential diplomacy' (Burges and Chagas 2017, Malamud 2014). Brazil's activism in South America is strongly associated with the government of President Lula and his Foreign Ministry Celso Amorin, who advanced South-South relations at global level, and in South America, by strengthening of Mercosur and creating UNASUR, as will be discussed below. This activism declined under the government of President Dilma Rousseff and even further after her impeachment in 2016, as Mello (2018) summarizes:

(...) since Rousseff's first administration (2011-2015), one could notice a continuous decline in Brazil's international image and projection, which had received a significant impulse during Lula da Silva's two mandates as president (2003-2010). Despite the fact that his successor preserved Lula's conceptual guidelines, foreign policy implementation progressively lost momentum and proactivity in the international front as well as centrality within the domestic political agenda. (...) The prolonged political crisis that led to the impeachment of President Dilma Rousseff in August of 2016, putting her vice-president Michel Temer at the head of the Executive, brought important repercussions for the conduction of Brazilian foreign policy. While still being sworn in as the interim minister of Foreign Relations, José Serra - a prominent politician connected to the opposition and former candidate in the presidential elections of 2002 and 2010 - pronounced a speech that seemed to indicate a profound reorientation in the strategies and priorities of Brazil's diplomacy (Mello 2018, p.1-2).

The new foreign policy orientation under President Temer included the alleged 'des-ideologization' of foreign policy (meaning the alignment of Party the Labour governments with other centre-left governments in the region); the promotion of free trade and the opening of markets for Brazilian exports; a strategic partnership with Argentina and efforts to revitalize and 'correct' Mercosur. Trade liberalization was a goal which meant a renewed relationship with traditional partners such as the USA and Europe; a focus on 'new partners' in Asia, particularly China and India; and a new approach to 'Modern Africa' focusing on commercial, investment and technology partnerships, correcting previous 'South-South strategy' (Mello 2018).

This new orientation, even if not abandoning Argentina, signalized a bilateralization of relations. The suspension of Venezuela from Mercosur and isolation of the country in other organizations, as discussed below for the case of UNASUR, reverted the previous approach of inducement change via engagement. Under 
Bolsonaro's government, these trends were radicalized. His Minister of External Relations, Ernesto Araújo, equated 'globalism' and the 'global order' with socialism in his inauguration speech and criticized newspapers such as the Foreign Affairs and the New York Times as vehicles of this (undesired) global order. He also stated that despite being against 'globalism', Brazil is a universalist country that wants to build something 'good and productive' with each partner; among the partners he included Israel, USA, Latin-American countries 'which liberated themselves from the Foro de Sao Paulo', 'those who fight against tyranny in Venezuela', the 'new Italy', Hungary and Poland. As for the UN system, he proposes a reorientation to strengthen sovereignty instead of NGOs interests, and to revitalize trade negotiations. ${ }^{2}$ Mercosur's future will depend on the reaction of its other member-states to this new situation, and the disposition to cooperate with a government which has a conservative socio-cultural platform, a discourse against human rights and the fight against climate change. The return of Kirchnerism to power in Argentina through Alberto Fernández in 2019 makes this scenario even more complicated due the deep ideological differences with Bolsonaro.

\section{UNASUR: A Process in Deep Crisis}

Despite the reiterated description in the media of UNASUR as a 'Chavist' or 'Bolivarian' initiative, the origins of UNASUR can in fact be traced back to the Brazilian project of creating a South American Free Trade Area that would be the result of the convergence between Mercosur and the Andean Community. This project was fostered by Minister Celso Amorim, during the government of President Itamar Franco, in 1994, in line with the ' $4+1$ ' strategy advanced to negotiate the FTAA, that is, to engage with external markets from group positions and avoiding bilateral negotiations with the USA. Following President Fernando Henrique Cardoso convened, in 2000, a Summit of South American Head of States and Governments in Brasilia, in which he proposed the creation of a South American Community of Nations (SACN). This latter would be a minimalist project that aimed to promote a convergence between the Andean Community and Mercosur. The SACN also promoted cooperation in infrastructure, with the creation of the Initiative for the Integration of the Infrastructure of South America (known in Spanish as IIRSA), established South America as a zone of peace and combat cooperation to terrorism. This regional initiative was established in Cuzco, Peru, in December 2004 (Briceño-Ruiz, 2010).

However, with the election of left-wing governments in Argentina and Brazil, and the activism of Venezuelan foreign policy under Hugo Chávez, the scenario changed. Chávez rejected SACN for two reasons: firstly, he considered that a new South America bloc could not be the result of the convergence of the Andean

\footnotetext{
${ }^{2} \mathrm{http}: / / \mathrm{www}$.itamaraty.gov.br/pt-BR/discursos-artigos-e-entrevistas-categoria/ ministro-das-relacoes-exteriores-discursos/19907-discurso-do-ministro-ernesto-araujo-durantecerimonia-de-posse-no-ministerio-das-relacoes-exteriores-brasilia-2-de-janeiro-de-2019
} 
Community and Mercosur because of their underlying neoliberal principles. Secondly, he considered South America as a single nation, and not a 'community of nations'. This idea was accepted in a Summit of South American leaders held in Margarita Island, Venezuela, in 2007, and the denomination SACN was replaced for UNASUR, formally created in May 2008 (Briceño-Ruiz, 2010).

Despite the initial Brazilian influence, Venezuela and its ALBA allies (Bolivia and Ecuador), and to a lesser extent Argentina, played the main role in the transformation of the SACN into UNASUR. Other countries such as Peru and Chile were also important players. As Comini and Frenkel (2017, p. 189) argued, UNASUR was the minimum common denominator of two models: one giving priority to the international markets and the promotion of relations with the rest of the world, called by them 'polygamic'; and another privileging regional markets and further relations firstly with the neighbours and, after consolidating those relations, with the rest of the world, referred to as 'concentric circles'. Therefore, from a modest and minimalist project that aimed to achieve a limited number of goals, integration in South America became a maximalist scheme with multiple political, economic and social objectives. New institutions were created in order to exchange information and best practices and foster common approaches in a number of issue areas such as the 13 sectorial 'Councils', the most active being the South American Council of Defence and the South American Council for Health.

UNASUR was considerably successful in its early years. Firstly, it contributed to the resolution the domestic crises in Bolivia and Ecuador, and the conflict between Colombia, Ecuador and Venezuela in 2011. The South American Council of Defence (SACD) was perceived as an original regional space able to counterbalance the US influence in military affairs, including ambitious goals such as the creation of a South America School of Defence (Frenkel, 2016). After the demise of InterAmerican Treaty of Defence (TIAR) in 1982, in the context of the Malvinas war, the Organization of Americas States (OAS) had lost its influence in the discussion of security and military affairs in the region. At least partially, the SADC was designed to fill the vacuum produced by the Malvinas War. UNASUR also advanced initiatives in the area of development and finance: the idea of creating a Bank of the South was part of a debate about a 'new financial architecture' for South America, able to mitigate the influence of International Monetary Fund in the region. IIRSA was perceived as a necessary instrument to improve the South American infrastructure and facilitate closer relations among the countries of the whole region (Palestini and Agostinis 2015). Cooperation in health became one of the most innovative in UNASUR (Ribeiro Hoffmann \& Tabak 2016; Yeates \& Riggirozzi 2017; Herrero \& Loza 2018).

While UNASUR allowed a dialogue between governments with different ideologies and views on economic and social issues (Mace, 2018), government changes in countries such as Argentina and Brazil after 2015, and the domestic crisis in Venezuela evidenced the weakness and shortcomings of the organization. The crisis in Paraguay launched by the 'fast track' impeachment of President Fernando Lugo was the first main failure of UNASUR in its role as mediator. Contrary to the crisis in Bolivia and Ecuador, the constitutional order was not restored in Paraguay; President Rodriguez replaced Lugo, and even if Paraguay was suspended of 
UNASUR, Asunción did not accept the regional intervention in the crisis. UNASUR also did not address the controversial impeachment of President Dilma Rousseff.

The case of Venezuela was even worst; this crisis was not only unsolved by UNASUR but triggered this bloc's decay. After the death of Chavez and contested elections in 2013, Venezuela entered in a spiral of conflict and violence. Manifestations in the streets demanded the end of Maduro's government in 2014. Led by the opposition leaders Leopoldo López, María Corina Machado and Antonio Ledezma, part of the Venezuelan opposition promoted La Salida (the exit) which meant the immediate resignation of the Maduro regime. The governmental response was military repression and the detention of Lopez accused of promoting violence and the death of 43 people. President Maduro initially accepted mediation by UNASUR, while rejecting the OAS, seen as dominated by US interests. Secretary General Ernesto Samper actively participated in the mediation efforts, but the political dialogue failed as Maduro's administration did not accept almost any of the opposition demands. In particular, the demand for a release of all political prisoners was rejected, and Lopez and Ledezma were both condemned to jail. Another attempt to mediate political dialogue in Dominican Republic in December 2017 was also unsuccessful. The failed UNASUR mediation transformed its image because the perception that it served the interest of the Venezuelan government increased.

Closa and Palestini (2015) argued that UNASUR was created to protect incumbent governments such as Morales, Correa and Lugo, and that the mechanism was never applied to a legitimate elected government that had decided to violate the democratic rules and practices, as was the case of Venezuela, or, one could add, Brazil under Bolsonaro. Riggirozzi and Grugel also noted that 'the fact that South American countries use UNASUR to defend democracy is not evidence...that UNASUR is part of a project of deep democratization or citizenship governance. UNASUR is willing to act to stop elected governments being overthrown, but it is not pushing for mechanisms to ensure citizen voice or representation' (Riggirozzi \& Grugel 2015, p. 796). The modification of the institution of electoral observation at UNASUR and the creation of the concept of 'electoral following' (acompañamiento electoral), in which non-governmental organizations (NGOs) would observe the elections without elaborating reports about the quality of elections, were also signals of weakening democracy in the region (McConnel et al. 2015).

The political changes which took place after 2015 with the election of right-wing governments further weakened UNASUR. A key factor that deepened the crisis was the inability of member-states to appoint a new Secretary General in 2017. President Macri, who was holding the Pro tempore Presidency, proposed José Bordón, a known Argentinean diplomat, but he was rejected by Venezuela. As consensus is required to make decisions at UNASUR, the appointment of a new Secretary General was suspended, leading to further paralysis. Argentina, Brazil, Colombia, Chile, Paraguay and Peru suspended their participation in the meetings of UNASUR institutions in April 2018. Afterwards, Argentina, Brazil, Colombia, Ecuador and Peru withdrew from the organization. More recently, Chile and Colombia proposed the creation of a new organization to replace UNASUR, the Forum for the Progress 
of South America (PROSUR in Spanish), but it is too soon to include this organization in the analysis.

\section{ALBA: When Domestic, Regional and Global Factors Matter}

Closely related to Chávez and Venezuela, but also influenced by Cuba, ALBA was presented as an 'alternative model' of regional integration with some characteristics which differentiated it from other regional organizations: first, no geographical contiguity among its members; second, absence of free trade as a goal, instead, a narrative allegedly based on solidarity and 'concertation'; third, open intention of being a 'non-capitalist' model of regional integration; and four, emphasis on the role of society (the people) in the integration process.

Initially ALBA was a Venezuelan unilateral initiative, announced by Chávez in the Summit of Association of Caribbean States held in Margarita Island, in December 2001, aiming at presenting an alternative to the US proposal of the FTAA, more radical than the ' $4+1$ ' strategy advanced by Brazil via Mercosur earlier. ALCA was the Spanish acronym for FTAA, and Chávez smartly opposed ALCA to ALBA, namely, the US interests to the Latin American ones. Norman Girvan summarized ALBA's goals:

Tariff protection for infant industries is allowed; public procurement as a tool of development is recognised; intellectual property rights are subordinated to the right to development and health; basic social services are, by implication, insulated from privatisation and commercialisation; special treatment for indigenous enterprises is assured there will be concessionary treatment of smaller and weaker economies; and the rights of labour and indigenous peoples are guaranteed (Girvan 2011, p. 164-165).

When Chávez met Fidel Castro in Havana, in December 2004, and ALBA became a bilateral initiative, opposition to ALCA was still the main (outward looking) goal; it did not have the clear-cut objectives in terms of projects to be implemented in the region beyond being linked by the Venezuelan government to the strategy of endogenous development furthered in those years by Chavez (BriceñoRuiz 2011). The paradigmatic shift in ALBA took place after 2006, a year in which Chávez adopted the twenty-first century Socialism as the ideological fundament of the so-called Bolivarian Revolution. From that year onwards, the shape of ALBA as a project for the region gradually emerged.

In terms of member-states, ALBA was widened to include new countries led by left-wing governments such as Bolivia under Evo Morales, Nicaragua ruled by Daniel Ortega and Ecuador led by Rafael Correa. Later, eastern Caribbean Islands such as Dominica, Saint Vincent and Grenadines, Grenada, Saint Kitts and Nevis and Saint Lucia became ALBA's members. Even Honduras under the José Manuel Zelaya's government participated in the initiative. Thus, ALBA became the unique regional group in the continent that included Caribbean, Central American and South American members with no contiguity, but ideological similarity. In 
substantive terms, ALBA defined more clearly its activities. Initially, ALBA was centred on the Venezuelan-Cuban axis, and the initial strategy was to replicate at Latin American level what they were doing bilaterally. Thus, social programmes in the sectors of education and health, the 'Misiones', were incorporated into ALBA in order to be implemented in other Latin American and Caribbean countries. In 2006, Venezuela launched Petrocaribe, and Bolivia promoted the idea of the Peoples Trade Treaty (Tratado de Comercio de los Pueblos-TCP in Spanish) as an alternative to the free-trade agreements fostered in the framework of the open regionalism. In 2008, Ecuador proposed the Unitary System for the Regional compensation of Payments (known in Spanish as Sucre), and the proposal of creating Grand national projects and enterprises was announced. At the institutional level, despite being an intergovernmental organization, ALBA included a Social Movement Council, an innovation compared to other regional institutions where the social participation was included only as mechanisms of consultation (Muhr 2012).

These initiatives were initially successfully implemented led by Venezuela as a paymaster, favoured by the high prices of commodities, particularly, oil. Some Grand nationals were announced such as in the sector of medicaments. ALBA also played a political role, particularly in the crisis in Honduras in 2010 (De La Torre 2017) and, to a lesser extent, in Paraguay in 2013 after the coup d'état against Zelaya and Lugo. It also developed joint positions at global level, for example, in the United Nations Framework Convention on Climate Change's (UNFCCC) conference in Copenhagen in 2009 (Watts and Depledge 2018). ALBA became to be seen as an 'alternative model' of regional integration, as their political leaders argued; the literature refer to it as a model of counterhegemonic governance (Muhr 2012); a new strategic regionalism (Aponte García 2014), an alternative to general law of capitalist accumulation (Seabra and Gimenez 2014) or a manifestation of decolonial delinking (Al-Kassimi 2018). Under the leadership of Chávez, ALBA, even with internal contradictions and excessive rhetoric, became a player in the regional affairs.

Notwithstanding these initial successes, ALBA showed clear shortcomings. Firstly, the borders of ALBA were never clear; some initiatives that the Venezuelan government considered part of ALBA were something different from ALBA for other countries, the best example being Petrocaribe. Secondly, ALBA was always quite dependent of the Venezuelan financing. Thirdly, many projects were not implemented and others just partially, such as the 'Peoples Trade Treaties' or the Sucre (see Chap. 7). Only few Grand national projects announced from 2008 to 2016 were implemented such as ALBA-Cultura, ALBA Pesca and ALBATEL (Benzi 2017, p. 84). Strategic projects such as ALBA- Alimentos (ALBA food) and ALBAMED (ALBA medicaments) did not advance. Fourthly, the impact on civil society, in particular the role of the Social Movements Council, one of the innovations of ALBA, was limited.

Peter Birle (2018, p. 166) argued that although the participation of civil society actors was rhetorically emphasized repeatedly, there was no real communication or decision channels available to achieve that goal. Moreover, ALBA did not attract other countries in the region such as Brazil, Argentina, Uruguay, El Salvador or 
Paraguay, when ruled by left-wing governments. Finally, as ALBA discarded free trade, the economic interdependence among the countries was weak, a factor pointed out in the literature as key or at least important to sustain processes of regional integration. Interdependence can also be achieved by promoting investments of the integration of production, for example through regional chain values, but these were not goals fostered. An Agreement of Economic Cooperation signed in 2013 by Bolivia, Cuba, Ecuador, Nicaragua and Venezuela in the framework of the Latin American Integration Association would be the basis to constitute the Economic Zone with Mercosur, but the lack of complementarity among the member of ALBA and Petrocaribe made a convergence difficult (Giacalone 2017, pp. 56-57). When right-wing governments took power in Argentina and Brazil in 2015 and 2016, the issue was excluded from the agenda of Mercosur.

To sum up, ALBA is a process in crisis as most of its goals have not been achieved, and as it suffered from the weakening of Venezuela, its paymaster. The global crisis that started in 2008 initially did not affect the agenda of ALBA because oil prices remained relatively high, and the demand for oil by China and India continued stable for some years; only in 2013, when the Chinese economic growth slowed down and when fracking became an important source of oil production that situation changed. The severe decline in oil prices to less than US\$ 30 in 2014 had an impact on the Venezuelan economy, with important implications on the development of the Bolivarian revolution, but also on the Venezuelan regional integration policy and ALBA. Mostly important, the death of Chavez in 2013 and the domestic political crisis and lack of regional leadership which have only increased since then have practically sealed ALBA's fate; its survival is closely related to the survival of President Maduro in Venezuela.

\section{Pacific Alliance: The Way Ahead?}

The Pacific Alliance was advanced by the Peruvian President Alan Garcia and included Chile, Colombia and Mexico. It can be seen as a follow-up from the Pacific Rim Arc initiative from 2007 that included countries from South and Central America and aimed at fostering a common economic approach towards Asia, and engaging with the megaregional negotiations, but was undermined by different approaches among free trade and left-leaning governments at the time. The election of centre-right governments provided a new opportunity to the advance of free trade at the regional level. The Pacific Alliance was announced in the Lima Declaration, signed in 2011, and this was followed by the Framework Agreement of the Pacific Alliance signed in 2012 and by the Additional Protocol of the Framework Agreement of the Pacific Alliance, subscribed in 2014. Durán and Cracau (2016) argued that the entry into force of the Additional Protocol marked an important step towards the regional integration effort, immediately eliminating tariffs for nearly $95 \%$ of intraregional imports and fostering economic integration through accumulation of origin and trade facilitation, and the formation of regional value chains. 
Legler et al. (2018) discuss the 'actorness' of the Pacific Alliance and argue that the lack of formal institutions and international legal personality is compensated by the existence of a 'web of agency' constituted by a number of actors engaged in the process of regional integration, which have provided security regarding its continuity and consolidation. They also argue that the ideologically based identity of the Alliance, confirmed by the commitment with neoliberalism, representative democracy, human rights and rule of law, compensates for the lack of geographic continuity, appointed in the literature as a hindrance for regional integration. In fact, the Pacific Alliance has a clear focus on the free trade agenda, in line with open regionalism, differently from Mercosur, UNASUR and ALBA at the time of its creation.

Scholars disagree as to what extent the creation of the Pacific Alliance contributes to the consolidation, or the fragmentation of Latin American regionalism (Heine 2016, Bernal-Meza 2015, Briceño-Ruiz and Morales 2017, Aranda and Salinas 2015). For those governments favouring free trade, the convergence between the Pacific Alliance and Mercosur is seen as an alternative to reunite countries, as supported by the Economic Commission for Latin America and the Caribbean (CEPAL), and discussed further below. But the fact that the Pacific Alliance does not include security in its agenda does not mean that its member-states are not involved in (geo)political considerations in the region; they did take parallel stances in the situation in Venezuela, for instance, what could represent a challenge in case of further escalation of the crisis. The rise to power of Andres Obrador in Mexico in 2018 has also raised the question of the stability of the neoliberal consensus among Pacific Alliance member-states (Legler et al. 2018).

\section{Concluding Remarks: Rising From the Ashes? South American Regionalism After the Crisis}

This chapter shows that Latin American regionalism is experiencing a period of crisis and redefinition. The crisis is related to a large extent to the effects of global financial crisis, and the end of the commodities' boom in key countries such as Venezuela and Brazil, which have acted as leaders of regionalism. ALBA and UNASUR are in deep crisis. After being presented as a 'new model of integration' based on solidarity and cooperation, ALBA suffers from the increasing deterioration of the Venezuelan economy, and the negative image of President Maduro's government. Even if the treaty of UNASUR is still in force, it is paralysed after most of its member-states suspended their participation or denounced its treaty. The creation PROSUR is an attempt to replace UNASUR with a less political and more free trade agenda. Mercosur is in a process of redefinition, the convergence with Pacific Alliance is in discussion, but the anti-globalist approach of Bolsonaro's government foreign policy and its prioritization of the USA and sole partner rise doubts about the Brazilian commitment to Mercosur. The Pacific Alliance did not evolve much beyond a network hub for pro-free trader stakeholders. 
Despite the uncertainties, possible scenarios are beginning to take shape. One way ahead would be the revival of UNASUR but, at least in the short term, this does not seem likely; the crisis in Venezuela has profoundly damaged its role in the region, and Brazil under President Bolsonaro's foreign policy of alignment with the USA and distance from South-South cooperation will not exert leadership. The protection of democracy has been key to UNASUR, but the recent crises, including Venezuela and Brazil, indicate that mechanisms developed are not robust enough to hold governments accountable. The worldwide crisis of democracy has further weakened the idea of democratic interference as countries become more zealous of sovereignty, and nationalist and extreme-right populism is on the rise. Sectorial cooperation in key areas such as security and defence, and health, key to UNASUR, were dismantled.

An alternative scenario would be a minimalist project based on the convergence in trade and the creation of regional value chains between a rolled-back Mercosur and the Pacific Alliance, but there are limitations regarding the complementarity of its member-states and the political disposition of Mexico under President López Obrador. PROSUR could evolve from this principle, but it is too early to assess this initiative.

We argue that the revitalization of Latin American regionalism could find a supportive pillar in the advancement of free trade, an agenda which could counterbalance protectionist trends, including the policies promoted by President Trump. However, the return of free trade should not be made at expenses of weakening the social and productive dimensions of regionalism. Both Mercosur and UNASUR have developed important social dimensions aiming at reducing asymmetries within and among their member-states in the last decades. Similarly, the integration of the production is still a goal to be achieved as Latin American countries must diversify their economies and become less dependent on the export of commodities in order to achieve sustainable development. To sum up, despite the uncertainties about the future institutional framework, a multidimensional integration that includes trade, the productive sector and infrastructure, as well as political and social areas is the way to deepen Latin American regionalism.

\section{References}

Al-Kassimi, K. (2018). ALBA: A decolonial delinking performance towards (western) modernity - An alternative to development project. Cogent Social Sciences, 4(1), 1546418.

Aponte García, M. (2014). El nuevo regionalismo estratégico. Los primero diez años del ALBATCP. Buenos Aires: CLACSO.

Aranda, G., \& Salinas, S. (2015). ALBA y Alianza del Pacífico: ¿Choque de integraciones? Universum (Talca), 30(1), 17-38.

Benzi, D. (2017). ALBA - TCP. Anatomía de la integración que no fue. Buenos Aires: Ediciones Imago Mundi - Universidad Andina Simón Bolívar. 
Bernal-Meza, R. (2015). Alianza del Pacífico versus ALBA y MERCOSUR: Entre el desafío de la convergencia y el riesgo de la fragmentación de Sudamérica. Pesquisa \& Debate. Revista do Programa de Estudos Pós-Graduados em Economia Política, 26, 47.

Bianculli, A. C. (2016). Latin America. In T. A. Börzel \& T. Risse (Eds.), The Oxford handbook of comparative regionalism. Oxford: Oxford University Press.

Birle, P. (2018). Führungskrise oder unvereinbare Zielsetzungen? Über die Schwierigkeiten und Herausforderungen regionaler Integration in Lateinamerika. In M. Koschkar \& C. Ruvituso (Eds.), Politische Führung im Spiegel regionaler politischer Kultur (pp. 159-178). Wiesbaden: Springer.

Bouzas, R. (2002). Mercosur: ¿ Crisis económica o crisis de la integración?, Notas preparadas para el Grupo de Reflexión Prospectiva sobre el Mercosur, FLACSO-Universidad de San Andrés, 2002.

Briceño-Ruiz, J. (2010). From the south American Community of Nations to the Union of South American Nations. Latin American Policy.

Briceño-Ruiz, J. (2011). El ALBA como propuesta de integración. In J. Altmann (Ed.), América Latina y el Caribe. ALBA: ¿una nueva forma de integración regional? (pp. 19-84). Buenos Aires: Teseo - FLACSO.

Briceño-Ruiz, J., \& Morales, I. (Eds.). (2017). Post-hegemonic regionalism in the Americas: toward a Pacific-Atlantic divide? Abingdon: Routledge.

Burges, S. W., \& Chagas Bastos, F. H. (2017). The importance of presidential leadership for Brazilian foreign policy. Policy Studies, 38(3), 277-290.

Closa, C., \& Palestini, S. (2015). Between democratic protection and self-defense: The case of UNASUR and Venezuela. Florence: RSCAS 2015/93.

Comini, N., \& Frenkel, A. (2017). UNASUR. De proyecto refundacional al fantasma del Sudamexit. Anuario de la Integración Regional de América Latina y el Caribe, 13, 181-207.

De La Torre, C. (2017). A Populist International? ALBA's Democratic and Autocratic Promotion. SAIS Review of International Affairs, 37(1), 83-93.

Durán Lima, J. E., \& Cracau, D. (2016). The Pacific Alliance and its economic impact on regional trade and investment: Evaluation and perspectives. ECLAC International Trade Series nr.128.

Frenkel, A. (2016). Entre promesas y realidades: La UNASUR y la creación de la Escuela Suramericana de Defensa. Relaciones Internacionales, 31, 33-52.

Giacalone, R. A. (2017). Principios económicos y narrativas políticas de las propuestas de reconfguración del orden regional latinoamericano. En N. Mellado, \& J. C. Fernández Saca, Desafíos para el regionalismo latinoamericano en el contexto internacional del siglo XXI (pp. 51-76). Antiguo Cuscatlán, La Libertad, El Salvador: Editorial Delgado.

Girvan, N. (2011). Is ALBA a new model of integration? reflections on the Caricom experience. International Journal of Cuban Studies, 3(2-3), 157-180.

Heine, J. (2016). Sigla nueva en sopa de letras: raíces y ramificaciones de la Alianza del Pacífico. Revista Mexicana de Política Exterior, 106, 35-48.

Herrero, M. B., \& Loza, J. (2018). Building a regional health agenda: a rights-based approach to health in South America. Global Public Health, 13(9), 1179-1191.

Legler, T. F., Garelli Rios, O., \& González, P. A. (2018). La Alianza del Pacífico: un actor regional en construcción). In E. Pastrana Buelvas \& H. Blomeier (Eds.), La Alianza del Pacífico: ¿atrapada en el péndulo del regionalismo y del interregionalismo? (pp. 143-172). Bogotá: Konrad Adenauer Stiftung.

Mace, G. (2018). Fracture de l'UNASUR? Crise du régionalisme sud-américain?. https://doi. org/10.13140/RG.2.2.16321.66407.

Malamud, A. (2014). Presidentialist decision making in Latin American foreign policy: examples from regional integration processes. In Routledge handbook of Latin America in the world (pp. 124-136). Routledge.

McConnel, S., McCoy, J., \& McCarthy, M. (2015). ¿Desafiando a norma? Acompañamiento electoral internacional en Nicaragua y Venezuela. América Latina Hoy, 70, 109-132. 
Mello e Silva, A. (2018) From Euphoria to Inertia: Brazil's International Rise and Decline, E-International Relations. Apr 29.

Merke, F. (2015). Neither balance nor bandwagon: South American international society meets Brazil's rising power. International Politics, 52(2), 178-192.

Muhr, T. (2012). (Re) constructing Popular Power in Our America: Venezuela and the regionalisation of 'revolutionary democracy'in the ALBA-TCP space. Third World Quarterly, 33(2), 225-241.

Oelsner, A. (2014). Articulating Mercosur's security conceptions and practices. In Regional organisations and security: Conceptions and practices. London: Routledge.

Palestini, S., \& Agostinis, G. (2015). Constructing regionalism in South America: The cases of sectoral cooperation on transport infrastructure and energy. Journal of International Relations and Development, 1-29.

Ribeiro Hoffmann, A. (2020). Mercosur between resilience and disintegration. In Weiffen B. and Nolte, D. Regionalism under stress: between disintegration and resilience. Europe and Latin America in comparative perspective. Abingdon: Routledge.

Ribeiro Hoffmann, J.Tabak (2016) Discussing Global Health and Access to Medicines in the UN System: The Case of the Union of South American Nations (UNASUR), The Hague Journal of Diplomacy, 12.2 (2016):178-196.

Riggirozzi, P., \& Grugel, J. (2015). Regional governance and legitimacy in South America: the meaning of UNASUR. International Affairs, 91(4), 781-797.

Ruvalcaba, D. M., Rocha Valencia, A., \& Durán González, T. (2016). Las potencias subregionales en el sistema internacional de posguerra fría: ¿nuevos actores en la política internacional? Geopolítica(s). Revista de estudios sobre espacio y poder., 7(1), 71-107.

Seabra, R. L., \& Gimenez, H. M. (2014). Contra o “vazio teórico" da ALBA, uma análise propositiva a partir da lei do valor. Revista de Estudos e Pesquisas sobre as Américas, 1.

Soares de Lima, M. R., \& Hirst, M. (2006). Brazil as an intermediate state and regional power: Action, choice and responsibilities. International Affairs, 82(1), 21-40.

Watts, J., \& Depledge, J. (2018). Latin America in the climate change negotiations: Exploring the AILAC and ALBA coalitions. Wiley Interdisciplinary Reviews: Climate Change, 9(6), e533.

Yeates, N., \& Riggirozzi, P. (2017). Global Social Regionalism: the case of the Union of South American Nations' health policy. PRARI Working Paper 15-10, Milton Keynes, The Open University.

Open Access This chapter is licensed under the terms of the Creative Commons Attribution 4.0 International License (http://creativecommons.org/licenses/by/4.0/), which permits use, sharing, adaptation, distribution and reproduction in any medium or format, as long as you give appropriate credit to the original author(s) and the source, provide a link to the Creative Commons license and indicate if changes were made.

The images or other third party material in this chapter are included in the chapter's Creative Commons license, unless indicated otherwise in a credit line to the material. If material is not included in the chapter's Creative Commons license and your intended use is not permitted by statutory regulation or exceeds the permitted use, you will need to obtain permission directly from the copyright holder. 